\section{〈研究ノート >}

\section{農業経営学における行動論的 思考の展開とその展望}

\section{1. 問題の所在}

今日, 日本農業の進路を考える上で, 個別農業経営 の志向を知ることはきわめて重要である.ところが， 実際の農業経営をみると，生産品目の多様化と屯応じ ながら，その志向はさまざまであるように見える. 企 業的経営に進むむの屯あれば，生業的に農業を営むむ のあある. また，生産にまつわる価值観屯多様化し， 多収益を第一の目標とするものから，たとえば安全性 を第一の目標とするあのまで，しだいにその幅は広が りつつある.

こうした志向の多様化を農業経営学はどのように受 けとめるべきなのか.

かつて農業経営学研究においては実践性をめぐる論 争があった．そてでは「理論の現実把握力」を重視す るか，それとあ理論の規範性を重視するかということ が争点になった ${ }^{1)}$ ，前者は実践性を即現実性と，後者 は実践性を政策上の規範性と考えたので, 議論は平行 線のようにみえた。 しかし実のところこの 2 面は深く つながっている．後者の論点が政策上の実践性にある といっても，現実の農家の動きを前提とせず，あっぱ ら規範論に終始するような理論では，意義ある政策的 効果は期待できない，つまり，政策上の実践性のため には現実の把握が前提として不可欠なのである.した がって，てのととと先の現状とを考え合わせるとき， 多様化する農業経営の現実を把握できるような理論を いかに構築するか，ということが現在的課題の 1 つと して浮かび上がってくる．乙の課題は，価格変動に対 する農業経営行動などを扱う短期的な行動論とは異な るむのの, 農業経営主体, とくに農家の長期的なあり

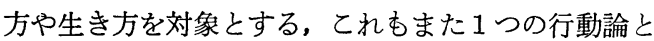
呼ぶべき分野に属する課題だといえよう.

さて，個別経営の志向が多様をきわめる 1 つの大き な原因は，農業経営における生産と生活の非分離にあ
ると思われる，農業においては，経営自体が一個の永 続体として経営者の生活から独立していないのがふつ うである. この問題は古くから家族経営における家計 と経営との非分離として指摘されてきた．また，農業 生産組織についても完全に一個の経営体として独立し ているむのは少なく，その多くは個別農家の寄り集ま り的性格を持っている. したがって，多様性を考察し ようとする場合, 農業経営を包み込む経営者の生活を あ視野に含めるととが少なくとあ前提となろう2)．多 様化の要因は他にも考えられようが，小稿ではこの生 産と生活の非分離を中心に考察したい。

てうした観点にたって従来の農業経営学を振り返る とき，さしあたり立論上の出発点になるのは，一般に 農家主体的衡論と呼ばれる理論枠組みであろう，周知 のように，“農家主体均衡論は農業経営ではなく農家を 基礎的な分析単位と考える。したがって，農業経営は それを包摂する農家行動の一活動領域となり，さらに その農家行動は農家の効用という本来的には主観的な 概念をひとつの柱として説明されるのである.この立 場は先ほどふれた論争の中の「理論の現実把握力」を 重視する側に相当するものであある.

小稿の目的は，乙の農家主体均衡論を 1 つの手がか りとしながら，農家行動論の枠組みを再考するととに ある. むっと屯, 現状の農家主体均衡論は多様化した 農家の志向の把握を主目的としていない，よっててと では，理論全体を直接に継承発展させるのではなく， 農家行動の根拠となっている農家の効用という概念に 焦点を絞り, その問題点と展開方向を探るととによっ て，新たな農家行動論の可能性を示そうと思う.

\section{2. 農家主体均衡論における効用概念の展開 之限界}

ここではまず，中嶋千尋の農家主体均衡論の理論枠 組みから検討を始めょう，中嶋の枠組みでは，企業が 「利潤極大原理」によって行動するのに対し，農家の 行動原理は「効用極大原理」であるとする，そして農 家の効用は，家族労働量と現物所得と貨幣所得との関 数として表わすととができるとする31. つまり，農家 行動の背後には「効用」というあのがあって, 農家は その「効用」を極大化するように行動するのだが，そ の「効用」は家族労働量と所得との関数として定義で きる，というのである．中嶋はこの農家行動の枠組み について，それ自体としてはほとんど説明をしない。 しかし，突然に設定された枠組みではなく，「チャヤ 
ノフの『小農経済の論理」(1923年)および大槻正男 の『農業労働論」(1941年) にまでさかのぼることが できる」〔中嶋：1983，PP. 14-15〕のである. ただし ，大梘の『農業労働論』における農家行動の枠組 み に関しては，さらにW. S. ジェヴォンズの考えを基 礎としているので，ててではそてまで遡って考察した (4).

まずジェヴォンズからみてみよう，大䞋が参照して いるのは, 労働量が生産物の限界効用度と労働の限界 苦痛度の一致点で決定されるという部分であるが5), ここではより根本的に，彼の体系における効用と経済 理論との関係をさぐっておきたい.

ジェヴォンズは周知のようにワルラス，メンガーと とあに限界理論の定礎者として名高い経済学者であ る. 彼はベンサムの快楽の理論に則りつつ, 経済学の 研究対象を以下のように設定する.

「最小の努力をもってわれわれの欲望を最大限に満 たすとと一一望ましいすのの最大量を望ましくないむ のの最小量をむって取得するとと一一別言すれば，快 楽を極大ならしめるととが経済学の問題である_(強調 原文)〔 Jevons : 1879, 訳, P.29〕と.

このような功利主義的行動観を基礎としながら，シ エヴォンズは経済の計算学を確立しょうとした. しか し, そのためには欲望の量的比較がはたして可能かと いうととに答えておかねばならない，そこで彼は，少

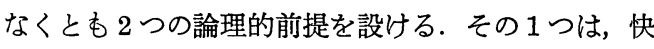
楽にはより「高い」あのとより「低い」あのがあり， そのうち「効用の計算学」として「われわれがててで 取り扱うのは最下級の感情である」とする論理である 〔ibid.訳, PP.19-21】. 快楽の高さはより道德的かど うかによって，低さはより肉体的かどうかによって判 断される. 彼はそうした中の「最下級の感情」のみを 対象とすることによって，快楽を計算可能なすのとし て取り扱えるとした．ての限定はかなり狭いあのと考 えてょい，たとえば「家族の要求」は「高い快楽」と して捉えられ，「最下級の感情」の部類に入っていな いのである〔ibid.訳, P.20].

2 つめ, 効用や快楽という個人的心理から出発し て，なぜ一般的な法則を論じることができるか，とい う問題についてである. この点については多少混乱が みられる.ジェヴォンズはいう。「私の理論は，あえ て1人の心意の状態を考究し，そうしてての考究を基 礎として経済学全体をその上に築くあのである」が， しかし，個人の総体を考えるとさまざまな特異的要因
は中和してしまい, 結局,「個々人に関してはまった く不定に見え，あるいはおそらく不定であるとてろの 諸問題が，大量および広範囲の平均に関しては，精密 な考究と解決とに耐えうるのである」と〔ibid.訳， PP.12-13]こてでは, 個人の総体がばらばらな個人の 単なる総和として考えられており，個人間の関係から なる社会の独自性が考虑されていない. しかし，ての 問題はおくとしても，ばらつきをあった個人の心意を 基礎として, どのようにその「平均」である総体を説 明しょうとするのか，あるいは「平均」的個人をどの ように見つけるのか, という問題が依然として残る. これもまた個人と総体社会との結びつきに関する問題 である.

以上の簡単な整理からわかることは, ジェヴォンズ ができる限り個人間の関係を捨象しながら理論を構築 しょうとしているととである. そして経済学とはそう いうあのだという限定を意識的に設けている。 それに 対し, 次にあげるチャヤノフは 1 つの個人間関係,すな わち家族という集団を理論の枠組みの中に取り込む.

ロシア農民をモデルとして理論構築をおこなったチ ヤヤノフもまた, 所得の限界効用と労㗢の限界苦痛度 の一致点で，労働投下量およびそれに応じた所得が決 定されるとしている. この点についてはジェヴォンズ と同様であるが，相違点は経済主体としての家族を設 定するところにある.

チャヤノフによると，家族はその内部における消費 者/労働者比率というかたちで, 所得の限界効用に影 響を与える.すなわち，家族内における消費者/労働 者比率が高くなると, 一定額における所得の限界効用 が大きくなり，逆に比率が低くなると限界効用す小さ くなるとする〔Tschajanow : 1923,訳, PP.45-48]. 乙 の理論の最大の特徵は，「専ら家族ならびにそれに基 づく諸関係のみが，賃労働なき経済の唯一の組織要素 でなければならぬ」[ibid.訳. P.9]という条件認識 であろう。この条件下においては, 家族は唯一の生産 的組織要素であると同時に, 唯一の生存の組織単位で あある.よって，先のような家族消費压力が問題とな るのだが, この場合, 労働者の行動を左右するのは労 働者個人のみからなる効用というょりあ，むしろ家族 という集団に基づく効用だといえよう.

チャヤノフの業績によって, 効用を考えるときの個 人はまったくのアトムとしての個人から, 家族という 制度の中での個人へと進展した. しかし，効用におけ る制度的要因への着目は，乙の理論においてはこれ以 
上進んでいない. 先の中嶋の理論をみると, 枠組みと して単に農家という単位を設定しているにすぎない し，消費圧力について屯，「農家の家族員として《被 扶養人員》1 人が加わったとしょう，そうすると農家 にとって必要な最低生存所得（三最低生活費）は当然 増加」し，「その農家にとっての貨幣の限界効用 $\left(U_{M}\right)$ を高める」〔中嶋：1983，P.74】と述へ，チャヤノフ の域を越えていない.

だが，家族という要素を組み込んだだけで十分な効 用の分析が保証されるわけではない，そこで，少し視 角をかえて効用概念一般に対する最近の批判をみてお きたい，消費行動の根拠としての効用概念に対して真 っ向から疑問を提示する者に，人類学者のM. サーリ ンズがいる，彼はある書物を，「本書は，人間文化が 実践活動からなりたち，その背後に功利的な利害が潜 んでいるという考え方にたいする, 人類学的な立場か らの批判にほかならない」と書きはじめ，「効用を作 りだすのは，文化だ」と言い切る〔Salllins : 1976,

訳, P. 1-2]. 文化 効用との関係を具体的に述へ ている箇所を抜き出すと次のようである.

「《効用》がある文化秩序に固有の《欲求》概念であ るかぎり，人々のあいだの示差的関係一一男女の衣服 間の色や線や織り方の対照が性の文化的価值を意味し ているように一一の表象を, 効用はモノの具体的特性 を通して必然的にあらわしているはずである.《欲求 の体系》はつ权相対的なものであり, 肉体的必要性 によっては説明できず，したがって定義上象徴的なむ のにほかならない」[ibid. 訳, PP.198-199]

こてで述べられているのは，主として「モノ」の效 用に関する潜在的な文化的要因についてである. しか し経済的行動のレベルでみても, その誘因を欲求概念 におき，それに基づく効用を行動の基準と考える場 合，そとには当然ながら文化の要素が入りこんでくる であろう，そのときの文化とは，家族を単位とした所 得の効用と労働の非効用という枠組みを超えるものに 違いない，このととは，別の言い方をすれば,「経済人 の思想に特徵的な功利主義的欲望観を拒否する必要が ある」〔西部：1975，P.28〕ということであり，人間 行動の合理性について再考するととにつながるのであ る.

一方，効用をいくつかのレベルに分類して捉えよう とする者むある. 経済学者であり同時に哲学者として あ著名なN. ジェオルジェスクニレージェンは, 効用 の前提となる欲求を 3 つに分類する〔N. Georgeseu-
Roegen : 1968]. 生物的欲求, 社会的欲求, 個人的欲 求がそれである. そして，乙のうち相互に補償しあい うるのは, 個人的欲求のうちのいくつかの屯のだけで あって, 他の 2 つの欲求は相互に還元不可能である, とする〔 [bid. 訳, 178-9]. つまり, 生物的欲求や社 会的欲求にあとづく効用においては，互いに無差別と いうことが存在しないという。したがって，そうした 䅨類の欲求をとり込むためには，従来の効用理論とは 違った枠組みが必要とされよう，その場合，生物的欲 求の方は比較的規定しやすい，食欲や睡眠欲など，自 然科学的な知識が援用可能だからである. それに対し て社会的欲求は多様である. 各文化でと, 場合によっ ては各小集団ごとに欲求の基準が異なると思われるか らである.したがって，主要な問題はての社会的欲求 の解明にある6 ${ }^{6}$.

しかし，乙れらの大問題をこの小論の中で正面から 展開することはできないし，そのための十分な準備も ない，そこで，もう一度農業経営学の分野に範囲を限 定し，乙の分野においておこなわれた効用概念の搪張 の試みについて，その成果と問題点を次に検討してみ るととにしょう.

\section{3. 農業経営目標論における効用概念拡張の 試み}

ここで取り上げるのは, 吉田忠ら7)の農業経営目標 論である. 彼らの立場を理解するために，その枠組み についてまとめた部分を少し長いが引用し，やや詳し く検討したい.

$\ulcorner($ ( )個別経済としての農家ないし農業経営を, 社会 経済から相対的に自立化し，一定範用内で自律的運動 をするあのとして把握する.

(口)その自律的運動の基本的な内的契機は，その個別 経済の経営目標であり，それにもとづく経営管理の客 観的な過程である.

(人)農家ないし農業経営の経営目標は，そてでの生産 手段の所有形態と労働力・生産手段の結合形態として の農業経営の類型ないし構造によって規定されるが， 後者は，個別経済をとりまく社会の経済法則によって 規定されている．乙のように経営目標を理解すると き, 経営管理を, 経営者の立場から目的手段合理的に のみみるのではなく，客観的歴史的にとらえることが できるようになる。

(二)以上の経営管理の客観的過程が，個別経営間の競 争を規定するが，さらにその積み重ねは，経営をとり 
まく社会的歴史的条件の変化による経営類型ないし経 営構造の変化に対して，1つの重要な規定的役割をは たす.

(杖以上のような個別経済としての農家ないし農業経 営の構造的な発展を, 1 つの歴史的過程として実証的 に研究していくべきではないか」〔吉田忠：1977， P.47]

この枠組みの意図を一言で表現するならば, "個別経 営の中に社会全体をみる゙とであ言えるだろうか。っ まり，個別経営は全体社会の中で相対的に自律しなが らむ，一方ではそれを取り巻く社会的歴史的条件によ って規定されるという認識である. そのとき，論理的 に2つの媒介項が設けられているととが上の引用から 知られる.ひとつは個別経営の経営目標であり，あう ひとつは生産手段の所有形態および経営類型, 経営構 造である. 所有形態, 経営類型, 経営構造をひとつと みたのは，経営類型が「社会体制を特徵づける歴史的 所有形態を典型的に反映する形で沈下固定された経営 要素によって構成される経営体」〔ibid.p. 80〕を指し ているからであり，またそうした「経営類型の移行形 態」同上〕を経営構造と呼んでいるからである。つ まり, 第 2 の媒介項については, 生産手段の「歴史的 所有形態」がその設定の基礎となっている.

との 2 つの媒介項のうち，まず生産手段の歴史的所 有形態について考えてみよう。まず，歴史的所有形態 は各社会体制に対応するすのとされる，具体的には， 社会体制の例として, 原始共産制, 奴隷制, 農奴制, 資本制があげられ，説明されている〔同上〕. しかし， 所有が一種の社会関係であるととを考えると，それぞ れの体制における所有形態は各体制全体内の他の社会 関係と相互規定関係をむつ，というょり，むしろ歴史 的所有形態とは社会体制そのあのであるともいえる.

したがって，農業経営を焦点とするばあい，そうした 歷史的所有形態がどのように個別経営に現われてくる のかという枠組みが必要になる。，そてで，大㭷の沈下 固定概念が利用される.

大㙕の沈下固定概念をとてで詳しく論じる余裕はな いが，ある生産手段が排他的かつ半永続的に当該経営 によって使用される関係にあり,さらにそれらが所有 と深く結びついているとき，その生産手段は当該経営 に沈下固定されていると呼ばれる，と要約してよいだ ろう ${ }^{\varepsilon}$. 乙の概念を導入するととによって, 時代時代 の歴史的所有関係は，個別経営の中に沈下固定された 生産手段の種類の違いとして, あるいは, 沈下固定の
程度の違いとして現われるというのである. そして, 時代時代に典型的な沈下固定形態によって経営類型が 設定され, そうした経営類型の移行形態が経営構造で あると定義される.

さて，あうひとつの媒介項である個別経営における 経営目標は,「それぞれの経営類型ないし経営構造に 対応して」〔同上〕見いだすととができるとされる. しかし，「農奴制的家族経営における封建地代納入と 生活欲求充足, 資本制企業における利潤追求, 社会主 義企業におりる公共需要充足」〔ibid. p. 80-81〕などと いう経営目標は,「抽象にすぎ」〔ibid. p. 81〕るとして しりぞけられる。そうではなく,「経営目標は, 所有 関係とはうらはらの関係にある分配関係の個別経済的 反映として, 経営主体に拉ける費用 (経営費) 意識を 規定し, 生産・販売過程における経営管理の判断基準 を与えるあのでなければならないっ〔同上】.つまり， この経営目標の次元にいたって, はじめて具体的な個 別経営における実証可能性が示唆され，それは大譛が 設定した費用意識としての経営目標よりもさらに広義 な概念である.

このように経営目標を広義に設定すると,農家の「効 用」と呼べるものに近くなる．吉田らはいう，「経営 構造としての自作農的家族経営は, 扗大する生活欲求 充足を基本的経営目標としており，その経済行動にお いて小農経済的経営純収益極大化としては一元化しえ ぬさまざまな「不純物」の混入がみられるのが一般で ある」そして，「てれを「効用」とよんであよいかむ しれない」〔同上〕という．乙の「効用」概念は，主 体均衡論的農業経営学派における「貨幣所得と労働投 下量の二要因の関数として」〔同上〕の効用概念とは 異なるとてとわられている. また，同書同章におい て9) は, 先の中嶋の効用理論を批判しつつ,「ある種 の「効用」を所与として，それから演繹的に説明する のではなく，現実の農家行動のなかから「効用」を帰 納的にとらえるという基礎作業からはじめるととがな によりも必要ではないだろうか」〔ibid.p. 28〕とも述 べられている.「効用」への帰納的接近法, すなわち 経営目標への帰納的接近法が強調されていると考えて よいだろう.

以上のところから, 吉田らの特徵は, 個別の農業経 営の中に歴史性を見出そうとしたとと，およびその歴 史性を体現するすのとしての経営目標あるいは効用」 を帰納的に明らかにしょうとしたてと，ての 2 点にあ るといえよう，そこで次に，「効用」をいかにして州 
納的に捉えるかという問題がでてくる.

とてろが，奇妙なととにこてで吉田らは自身の近代 化論を導入して,「効用」の. 展開過程を論じてしま う.すなわち, 「家族経営が商品生産の深化とともに 資本制企業への転化を準備するなかで，経営目標は小 農経済的純収益へと「純化」されていく」「ibid.p.81〕 というのだ. そして他方では，「兼業化の進展のなか でそれぞれ独自の形態と内容の「効用」体系をむった 多様な農家群があらわれ」〔同上〕るとする.

これでは先の論理と矛盾する. 経営目標すなわち 「効用」を㷌納的にとらえ，その分析を通じて個別経 営のなかに歷史性を見いだすという枠組みを設定した にすかかわらず，結果として考察されるはずの歷史性 が最初から与えられているのである. 吉田らがてう言 わざるをえなかった理由は，多様な形態の農家「効用」 そのものの分析手法が確立していないということに尽 きよう(1).

以上, 吉田らの著作をとりあげ, その論理構造と問 題点について検討してきた，その結果, まず農業経営 学研究に歴史性と帰納的な研究法を持ち込もうとした ことが注目された。このうち帰納的研究法については 問題があったが，他方，歷史性を導入しょうとした意 義は大きいといえよう.やややすすれば対象を個別経営 の枠内に限定してしまい，結果として，より大きな社 会経済の動きに対して無批判的になりがちな農業経営 学を, 歴史性を映し出す一個のミクロコスモス研究と して捉える手法は魅力にあふれている. 個別経営を分 析しながら, 社会全体についての考察もできるからで ある。

ただし吉田らのいう歴史性には, 経営目標の「純化」 過程に関する近代化論から知られるように，マルクス 経済学的発展論が色濃く含まれている．乙れが䚻納的 研究法と相容れないのは明らかである.だが，行論の 過程で 1 つのメルクマールとなった生産手段の「歴史 的所有形態」という概念は，有効であると思われる ${ }^{11}$. 生産手段の所有形態，あるいは労働力をあ含んだ生産 要素の利用・処分等に関する権限のあり方は，農業経 営の目標と相互規定的であり，したがって農家の生産 面における行動を規定するあのとなろう。しかし，最 初に述べたように，農家の 1 つの大きな特徵は生産と 生活の非分離にある. 生産手段あるいは生産要素の所 有形態への注目によって，農業経営の歷史性の分析は 可能になるだろうが，農家行動の把握のためには生活 面の分析む同様に必要となろう。つまり, 多様な形態
の農家「効用」を考えるには，少なくとも農家の生活 面をむ対象に含める必要があり，しかむそれは帰納的 分析手法によって捉えられなければならないのであ る.

\section{4. 生活の側の行動原理}

効用概念に対する制度の導入，文化の要因や社会性 の問題などが先のとてろで明らかになった留意点であ った. ミクロコスモスとしての個別経営あるいは個別 農家を対象とするような農業経営学の枠組みにあって は，生産面より屯生活面の中にそうした制度や文化， 社会性が集中的に現われるといえよう。

ところで，農家行動分析に文化等の概念を導入しよ うとした試みはもちろん皆無ではない。たとえば高橋 正郎は，「農業における企業的展開の論理を解明」す るにあたって「文化構造」という概念を参照し，その 規定力を問題にした〔高橋正：1968】.また石田正昭 は，社会学者の惠口濱俊がいう「間人主義」の概念を 援用しながら，日本農村の実情に準じた経済モデルを 構筑しょうとしている[石田：1988].しかし，高橋の いう「文化構造」は「社会総体的な概念」すなわち 一国レベルや時代レベルの概念であって，多様性を捉 えようというここでの問題にはなじまない，他方，石 田の「間人主義」モデルは，意思決定に至るまでの農 家の行動様式を主に問題としているといえる． 石田に よると，わが国農村における「行動原理」は，「絶対的 な善悪ではなく，状況のなかでのふさわしさを基準に 行動するということであり，そのときどきで行動が変 わりうる」というような「状況中心の行為」として捉 えられるという。これは，何が農家行動の誘因とな り，何が農家にとって効用と感じられるのかという小 稿での問と比較すれば，そうした行動の目標に至る過 程における行動椂式と位置づけられよう．また，この ような行動様式論はそれ自体の中に変動論を取り込め ないので，宿命論に陥り易いという弱点あある.

問題は農家生活の把握にある．その場合にまず重要 となるのは，生活における秩序の存在であろう．た之 えば,ながく農家生活把握の鍵となってきたイエ・ム ラ理論も，イエやムラが農村生活における主要な秩序 を形成し，それらが行動規範となっているととを表わ したあのである. しかし，近年においてそのイエ・ム ラ理論の妥当性が疑問視されつつあるように，そうし た生活の秩序は不变ではない，時代ととあに変化する のである．だが，生活の秩序は自らの生活を支える人 
々を前提としているので， 1 個人の意志によって急激 に変化するあのではない，最終的には，秩序の作用す る範囲の人々全体によって受け入れられなければ, 秩 序の変化は起こらないのである. したがって, 生活秩 序の変化は旧来の秩序を利用・改良するというやり方 に落ちつかざるをえないであろう．旧来の秩序の延長 線上でなりれば，人々の合意が得にくいからである. 現在の生活が過去の生活秩序を前提として成り立つと いう意味で，乙の点は生活における歴史性と呼ぶてと ができる.

あう少し具体的に考えよう. 先述のように, 従来, 農家を捉える枠組みとしてイエ (家) 理論がよく持ち 出されてきた，そてでまず，イエ理論における生活単 位としての農家の捉え方について検討したい。

家は長らく農村社会研究の中心とされてきたので, それに関する数多くの研究成果があるとともに見解あ 多様である．たとえば，家を歴史的構成体と考えると “家は解体した”ということになる，しかし，家を文 化的連続体と考えるならば，時代時代の社会経済的条 件に制約されながらあ連綿と存続するすのとなる．乙 の点について，たとえば歴史学者の我棌子麟は次のよ うな枠組みを用意する ${ }^{12)}$ ，我孫子はまず，「家とは家 族が生き続けるための組織である」という超歷史的な 視角と,「家族が家によってどうやって生き続けられ るかという機能」にかかわる視角とを区別する．そし て，律令制下の郷戸から近代の労動者家族にいたるま で，それらは前者の視角においてはすべて家であると いえるが, 後者の視角に抢いては, 「各段階の家は異 なってくる」とする.つまり彼は, 家族労働力, 家業, 家産の関連を「家族二労働力, 家産二生産手段によっ て遂行される生産が，家業である」と捉えるが，そう した生産体としての家は時代によって变化する. しか しその一方で, 超歴史的視角からみた家も認めるので ある(3).

乙の超歴史的視角からみた家は，具体的には，いま ある家を維持存続させようとする力として現われると 考えられよう，家の現象形態はその時々の条件によっ て変化するので，乙の力は絶対的なものではない，し かし，家が「家族が生き続けるための組織である」か らには，その变化は家の維持存続を前提としたあので なければならない，あるいは生活を設計する場合，生 活体としての家がつねにその基盤に位置づけられると いってもよい，よって，生活体としての家をいかに維 持存続させるかということは, 農家が長期的な視野に
たって行動する場合の，1つの根本的な目標であると 考えてよいだろう(14).

家の維持存続という農家の根本目標を設定すると, それに基づく行動は, 家を生活単位とするととから 2 つのレベルに分けて考えることができる，ひとつは家 内部における家維持存続の行動であり，もうひとつは 家間関係における家維持存続の行動である.

このうち家内部における家維持存続行動について は，農家家族の問題として近年取り上げられつつあ $ろ^{15)}$. 乙の点は家族農業経営と直接に関連するので問 題が見えやすい. しかし，家間のレベルでの家維持存 続行動む同様に重要である. かつては水利や林野の共 同利用などの経済的共同がなければ，農家は自己の経 営が成り立たなかった，もっとも，そうした経済的共 同は現在ではしだいに必要性が低下しているが，家の 自立が生産・生活面において完全に達成されたともい えないであろう，とくに，生活面においては，今日で あ他の家々との関係に依存している部分が多い.また， 家内部の問題に由来する行動のように見えるすので あ, 実は家間関係がその基礎となっている場合あある. たとえば「先祖伝来の土地」という観念があるが, 高橋正郎はてれを以下のように説明する.

「農家の人々が重視しているととは，その伝来の土 地そのあのではなく，土地に媒介された，地域社会に おけるイエとイエとの関係である. 農村において, 農 地を保有し，それに伴う義務を分担することは，その 社会における一定のステイタス（地位）を獲得するこ とであある」‘高橋正：1987，P.219]

「先祖伝来の土地」という観念はこれまで家産意識 という家内部のレベルから説明されるととが多かった がむしろそれは生活の場において一定の地位を保持 するために土地を保有するという家間レベルの意識を 反映するあのだ，というのである ${ }^{16)}$. 地位の準拠社会 としては, 高橋も指摘するように, 現在においてもやは りムラなどの近隣集団が重要になってくるであろう.

こうした家内部, 家間における農家の家維持存続行 動には, 先の生活秩序に関する議論があてはまる. 家 内部においては，いわゆる家意識が歴史的に形成され てきた秩序であり，その利用・改良が問題となる. 家 間においては，近隣との間にあるさまざまな秩序とそ の利用・改良が問題となる. なかであ後者は, 地縁的 関保が重要視されるわが国農村にあってはとくに重要 である. 近隣生活の秩序は近隣に住む人々の相互主観 に基づいているが，变化の受け取り方に統一性が保証 
されないため，新たな合意を得るには，とりあえず合 意のできている既存秩序から出発するしかないからで ある.

また，乙てで直接問題となるのは，農業経営に影響 を与える範囲での農家生活である，具体的には，生産 要素である土地・労働力・資本の利用や処分に及ぼす 生活面からの作用というととになる，乙のうち資本は 比較的に個別的なので除くとすると，他の土地・労㗢 力の利用や処分は, 農家の生活面に左右されることが 多い，家内部においては，土地相続の問題や家族労働 組織の問題などが焦点となる．家間においては，分散 錯围制からくる土地規制や，家を越えた労働力編成に おける近隣関係の影響などが直接的な現われである.

農家は家の維持存続を目標とするから，その制約内 でこうしたさまざまな関係をうまく運営していかねば ならないといえよう.家内部において, 家の維持存続と いう目標は家族構成員間の関係の変化を家維持存続に 合致するような関係へと導くが，その場合個々人の意 志との間がうまく調整・運営されなければならない.他 方, 家間においては, 他の家々との関係をうまく運営し 自家の維持存続を実現しなければならないのである.

こうした行動原理を家の維持存続を目標とする関係 運営原理とよび，農家の生活面における行動の解明に 際して，基碟的な枠組みを与えるあのとして位置づけ たい、この原理の抽象度は高いが，先の「間人主義」 的行動原理と比べると变化屯报えるし，したがって宿 命論に陥る危険性も少ない177。なぜなら，現在におい て存在する関係は歴史的変遷の結果であり, その関係 を自家の維持存続という目標に向かって運営するのだ から, 多分に各構成員, 各家々の裁量が考慮に入って くるからである.

この原理を家内部にあてはめて考えた場合，やはり 従来いわれてきたような家意識が運営すべき家成員間 関係を捉える出発点となろう．他方，家間レベルでの 関係は地域的な多様性が大きいので, 個別事例のなか で明らかにし，それを農家行動の分析に用いなければ ならない.しかし，先にあげたような地位保持のため

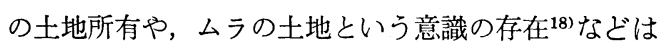
家間の生活秩序として，かなり広い地域にわたって特 定できるであろう.

とああれ農家の生活面における行動をさぐることに よって, 抽象度は高いながらも, 家の維持存続を目標 とする関係運営原理という1つの原理を導き出すとと ができた．この原理は，具体的には運営すべき現時点
での関係が問題となるため, 先述したように実証研究 のための枠組み的性格が強い. しかしながら, 生活に おける歴史性および生産面とのつながりを実証研究に おいて取り込めること，さらには家間関係をむ視野に 含めながら個別農家あるいは個別経営を考えうると と，乙れらの点にての枠組みを設ける意義があろう.

\section{5. おわりに一今後の展望一}

小稿で扱った農家行動は比較的長期の視点にたった 農家行動である. 価格変動への対応などの農家行動に ついては, 従来の農家主体均衡論の範囲内でもかなり 説明可能であろう. しかし, この理論をつきつめてゆ くと農家生活の分析が必要となることも事実なのであ る.

その結果, 家の維持存続を目標とする関係運営原理 が導かれたが，乙の原理に基づく効用は量化がきわめ て困難である. よって, 量的概念によって均衡点を求 めて行動を説明するのではなく, 記述的な説明方法を とらなければならないであろう。

最後に, 残された問題についてふれたい. 最初にこ 々わったように, 個別経営の志向の多様化の要因はさ まざまである，たとえば，以上の枠組みでは経営者の 価値観の多様化については十分に捉えられないかすし れない，そうした動きの中には従来の生活の枠組みを 超えた関係に依拠するものが含まれているからであ る. それらは各経営者自身の中の規範に重点をおく行 為19)として別に考えられなければならない。しかし， たとえ個人的規範が重視される経営であっても, 特定 の土地に住み, 特定の土地を利用する以上, たとえば 近隣との関係をうまく運営していく必要が生じょう。 また, 何度かふれたように, 関係運営原理は抽象度の 高い概念なので, 運営すべき具体的な関係については 経験的手法によって明らかにされねばならない. しか し，乙のことは農家効用を実証的に明らかにする場合 には当然のととである. したがって, 実証研究の中で この枠組みの有効性を検討すること, これが次のステ ップとなろう.

注 1)との論争のまとめとしては〔拈田：1977，74〜 77頁】を参照.

2) 和田照男はての点に関連して,「経営問題の㑡か らみる限り, 農家は家族農業経営すなわち「世带 単位で営まれる経営」ないしは「世带主が経営老 であり家族員を主たる従業員とする個人業主経 
営」として把握すべき」、〔和田：1979，14頁】と し，経営者の生活と農業経営とを分離しようとす る. 農業経営学の守備範囲に関する立場の相違と いえよう。また，和田の所有観については，注11 を参照.

3）〔中嶋：1983，13～33頁]参照.

4) 大㚘が農家主体均衡論の発展に寄与しなかった わけではない. ジェヴォンズの枠組みは労働者家 計のものであったが, 大槻はそれを農家の分析に あてはめた. また，チャヤノフの図表化との対比 においても, 論理的にすぐれた点がある（詳しく は〔中嶋：1958】参照).しかし, 効用概念自体に 関する検討はなされておらず，それについての新 しい展開はなかったとみてょい。

5) ただし、ジェヴォンズは「限界」という用語を 使っていない.

6) しかし, 彼の欲求の 3 分類に問題がないわけで はない，彼はこれら 3 つの欲求のうち生物的欲求 を最す重要なすのとして位置つけているが，民族 誌をひもとくまでもなく，単純な序列化には問題 があろう。

7）以下に引用する筒所には, 吉田忠が単独で執筆 している部分と, 乗本秀樹との共同討議の上で執 筆している部分がある。しかし，共同討議による 部分にも思考の一貫性が認められると考え，それ らの意見を「吉田ら」の意見とし，一括して扱う。

8 ）〔吉田：1977〕第 2 章第 2 節，あるいは[大梘： 1948]等を参照.

9）乙の箇所は乗本の執筆分担からの引用である.

10）この問題点については，先の分担執筆者である 乘本すすでに気ついているが「「うした不十分 さは，経営を「独立体」としてとらえるための概 念である「沈下」の宿命であろう」とし，枠組み そのあのの見直しには至っていない〔乗本: 1978 , 40頁].

11）和田照男む生産要素の所有を重視し, 所有の多 義性を企業形態論の軸と考えているが，和田は所 有関係について, その歴史性よりもむしろ機能面 を重視している[和田：1978]. それゆえに，とと で吉田の論について述べたような論理の行き詰ま りは出現しないと考えられるが，他方，あくまで 形態論にとどまり, 企業形態の展開があつ意義を 描きにくいように思われる。

12）以下，我孫子の引用は[我孫子：1989】ょり.

13）こうした家の捉え方は我孫子に限らない。高橋 明善む，家のおかれた外部的条件を重視しつつ， それと連続性との絡み合いで家の変動を捉えよう としている〔高橋明 : 1988].
14）こうした超歴史的視角からの家は，機能的にい えば, 生活保障組織としての家といえるだろう。 だが，生活保障組織としての家といえども農家生 活にとって未来永劫に至るまで必要とされるかど うかについては確答できない，家は社会経猟的条 件によって変化する面をむつからである，よって この答は時にまかせるしかないが，小稿ではさし あたり有効であろうという考えのあとに家維持存 続の目標を設定した．従来の家にまつわるイデオ ロギーを強化するつむりはないが，生活における 想像力には限りがあり，乙れまでの歴史において あそうであったように，幸せの追求のあり方がそ う容易に変化するとあ思われない. また生活保障 というだけでなく，家は先祖祭祀の単位としてあ 永続を要請されよう.

15）たとえば〔大内：1988】.【石原：1988】など.

16）たとえば渡辺兵力も，他の家との社会関係を前 提とした家（農家）の定義を案出している。【渡 辺 : 1976]参照.

17）生活単位としての家を設定したときの「宿命性」 に関する筆者の考えについては，注14を参照.

18）たとえば〔川本：1983〕などを参照.

19）先に石田が参照した濱口によれば，日本人の行 動様式は「標準型行為」, 西洋人の行動様式は「規 笵型行為」と概念化できるという. この分類に従 うと, 自らの価值観に基づく経営行動は, むしろ 後者の行動様式に合致するといえよう。【濱口： 1977】 参照.

\section{<文 献 $>$}

- 我孫子 麟：1989「家・家族・家産・家業」村落社 会研究会『研究通信』N 0.155

- 石田 正昭：1988「稲作経営の課題と展開方向」 『農林業問題研究』93

-石原 豊美：1988「農家家族の多様な展開」村落社 会研究会『研究通信』N No. 153

-大内 雅利：1988「現代の農家」『日本の農業』165

-大柣 正男：1941『農業労働論』(『大槻正男著作集 第 2 巻』1977, 楽游書房, 亿採録) : 1948 「農業に於ける純収益及び所得の 両概念」『農業と経済』15-9

-川本彰：1983『むらの領域と農業』家の光協会

- 高橋 明善 : 1988 「変化する農家家族を把えたい」 『日本の農業』 165

・高橋 正郎：1968「農業経営研究方法に関する一省 察一経営史学の方法と関連して一」 『農業経済研究』39-4 1987 地域農業の組織革新』農山漁村 
文化協会

・中嶋 千尋 : 1958 「農家の主体均衡の図形表示につ いて」『農業経営経済学の研究（大柣 正男還暦記念)』羔賢堂

: 1983『農家主体均衡諭』富民協会

・西部邁：1975『ソシオ・エコノミックス』中央 公論社

- 乘本 秀樹：1978「家族農業経営の構造論的把握に ついて一方法諭的考察一」『農林業問 題研究』52

・濱口 恵俊：1977『日本らしさ」の再発見』日本経 済新聞社

・占田忠編著：1977『農業経営学序論』同文涻

- 渡辺兵力 : 1976「農家之村落の相互規定」『村落 社会研究』第12集

- 和田照男：1979「農業生産組織の企業形態論的分 析方法」『農業経営研究』17-1

- Jevons, W. S. : 1879 "The Theory of Political
Economy”（邦訳『経済学の理論』 1981, 日本経済評諭社)

- Reorgescu-Roegen, N. : 1968'Utility and Value in Economic Thought', in "Dictionary of the History of Ideas" Philip P. Wiener (eds.)（邦訳「経済思想にお ける効用と価值」『経済学のメソドロ ジー』1988, 平凡社)

- Sahlins, M. : 1976 "Culture and Practical Reason" (邦訳 $\boldsymbol{r}$ 人類学と文化記号論』1987, 法政大学出版局)

- Tschajanow A. : 1923 "Die Lehre von der bauerlichen Wirtschaft. Versuch einer Theorie der Familienwirtschaft im Landbau” (邦訳『小農経済の論理 [増訂版】』1957, 大明堂)

（筆者・三重大学生物資源学部） 